\title{
BIO-COAL PRODUCTION WITH AGROFORESTRY BIOMASSES IN BRAZIL
}

\author{
Lucas de Freitas Fialho ${ }^{I, \star}$, Angélica de Cássia Oliveira Carneiro ${ }^{1}$, Ana Marcia Macedo Ladeira Carvalho ${ }^{1}$, \\ Clarissa Gusmão Figueiró ${ }^{1}$, Carlos Miguel Simões da Silva ${ }^{1}$, Mateus Alves Magalhães ${ }^{1}$, \\ Letícia Costa Peres ${ }^{1}$
}

\begin{abstract}
Pyrolysis is a promising technology for thermal conversion of lignocellulosic biomasses into a higher added value fuel. The aim of this study was to analyze the potential of four agroforestry biomasses to produce energy as a raw material or as a bio-coal. In this study, slow pyrolysis was conducted in three final temperatures to evaluate the bio-coal production of four agroforestry biomasses widely available in Brazil. The biomasses used were sugarcane bagasse (Saccharum sp.), bamboo (Dendrocalamus giganteus), straw bean (Phaseolus vulgaris) and eucalypts wood chips (Eucalyptus $\mathrm{sp}$.). In the first part was presented the raw biomasses proprieties, such as lignin, carbon, hydrogen and ash contents. In the second part was showed the bio-coal proprieties, such as gravimetric and fixed carbon yields, fixed carbon and ash contents. These bio-coal results were showed as a function of final temperature of pyrolysis. The best energy indicators for bio-coal production, such as fixed carbon yield, high heating value, was observed in the bamboo and eucalypts. The bagasse and straw bean biomasses have high concentrations of ash and low lignin content when compared with the other biomasses assessed and are less suitable to produce bio-coal.
\end{abstract}

Keywords: Chemical composition, energy, pyrolysis, temperature, yield.

\section{INTRODUCTION}

Policies and proposals have been implemented for supporting renewable energy utilization due to the rising concern about to the increase in the anthropogenic emissions of the greenhouse gases (GHG) and energy security of the countries across the world. In the United States, the Renewable Fuel Standard program (RFS) attempts to decrease the greenhouse-gas emissions and expand the renewable fuel sector of the country while simultaneously minimizing the dependence on imported oil by the Energy Policy Act of 2005 (USA 2005). In the European Union, Energy Roadmap 2050 outlines plausible ways to ensure that at least $55 \%$ of the gross final energy consumption until 2050 should be drawn from renewable-energy sources (European Commission 2012).

A substantial environmental and socio-economic advantage can be achieved with the use of biomass as an energy supply (Carrión-Priet et al. 2017). However, raw biomass reveals certain undesirable properties for energy purpose viz: heterogeneity, low energy density, high moisture and low grindability (Sermyagina et al. 2015, Bach and Skreiberg 2016, Grassmann et al. 2016, Ramos-Carmona et al. 2017). To solve these issues, some treatments can be applied such as biochemical or thermochemical processes, which could improve the chemical and structural characteristics of the material. The biochemical process, such as digestion and fermentation, typically produce methane and alcohol (Limayem and Ricke 2012, Kwietniewska and Tys 2014). In the thermochemical process, there are various pathways of conversion, such as pyrolysis, gasification, combustion, hydrothermal liquefaction and hydrothermal carbonization. 
Pyrolysis technologies are routes for thermal conversion of the lignocellulosic biomass into a higher added value fuel. Pyrolysis routes are classified as slow, fast or mild according to the combination of temperature, time and heating rate used. All these technologies consist of subjecting biomass to a controlled heating at low-oxygen conditions to the thermal depolymerization of organic matter (Dhyani and Bhaskar 2017). Slow pyrolysis, also called carbonization, is a one of the most known routes for biomass processing (Wang et al. 2017). It has as a main product a solid fraction called bio-coal, a fuel with high carbon and energy contents per mass unit. The other routes are promising technologies and still in an initial stage of development on an industrial scale. The main products of fast and mild pyrolysis are the bio-oil and the torrefied biomass, respectively (Grassmann et al. 2016, Wang et al. 2017).

The bio-coal production from the slow pyrolysis of biomass is still a technology with relevant challenges to consolidate in the worldwide energy market. Brazil is one of the countries with the greatest growth potential in this market due to its history of bio-coal production and consumption, leading this market due to the domestic consumption of the steel industry to produce pig iron. The bio-coal is used as a charcoal - a carbon source - in the process, and it is produced exclusively from wood logs to have the specific indexes of mechanical strength, density, and average size for steel production. The other biomass sources were historically overlooked because they did not meet all the desired quality indices for this purpose. However, this scenario has changed with the current interest in renewable-energy sources, and Brazil must enter this market since it has favorable agricultural and forestry conditions to meet the demand for sustainable fuels.

In this context, the aim of this study was to analyze the potential of four agroforestry biomasses to produce energy as a raw material or as a bio-coal, and their properties. The pyrolysis process was conducted to three different final temperatures. The influence of the biomasses and the final temperature on the bio-coal yield were studied.

\section{MATERIALS AND EXPERIMENTAL METHODS}

\section{Biomasses}

Four agroforestry biomasses were used: sugarcane bagasse (Saccharum sp.), bamboo (Dendrocalamus giganteus), straw bean (Phaseolus vulgaris) and eucalypts wood chips (Eucalyptus sp.). Biomasses were selected (presented adequate phytosanitary conditions) and collected in 2017 on production farms located in the interior of the state of Minas Gerais in Brazil. The city is located at $658 \mathrm{~m}$ altitude, and the region climate was classified as humid subtropical climate (Cwa) according to Köppen's climate classification.

These biomasses were chosen due to their composition and structure characteristics. Furthermore, for the following reasons:

- Sugarcane bagasse: the fibrous residues of processing of sugarcane for production of ethanol and sugar. In general, approximately $28 \%$ of the sugarcane mass is converted in bagasse (Cerqueira et al. 2007). This residue is produced in large scale in Brazil due to the huge sugarcane planting area in this country. Brazil was responsible for 39,7\% of sugarcane production in the world in 2014 (FAOSTAT 2017).

- Bamboo is a perennial woody grass with ample distribution in the world. Some studies with different source or culture condition have shown the higher growth rate. This growth characteristic of bamboo is an advantage for bio-energy production and lignocellulosic biomass resources (Jacalne 1978, Sokhansanj et al. 2002, Pordesimo et al. 2004, Zhou et al. 2005, Nath et al. 2008, Varvel et al. 2008).

- Straw bean: the residue of production of the bean. The bean is one of the most basic and essential food in the Brazilians meal. The bean crops are widely performed in all territory of the country. The high climatic adaptation and the soils conditions ensure this product during all year (Heinemann et al. 2016). These characteristics contribute to Brazil to be the third largest producer of beans in the world. (FAOSTAT 2017)

- Eucalypts wood chips: Brazil has high forestry productivity and this material is highly available. For eucalypts, the approximately value of annual average increment is $36 \mathrm{~m}^{3} \cdot \mathrm{ha}^{-1}$.year ${ }^{-1}$ (IBÁ, 2017). The rate of growth of these plantations confers to Brazil competitive advantages in relation others country. Conditions of climate, soil, territorial extension, labor and infrastructure are the main factors that contribute for this scenario (Valverde et al. 2004). 
Sugarcane was planted in the year-and-middle system, it was harvested 18 months after planting. Bamboo was harvested 60 months after planting and straw bean was collected from a bean plantation harvested with 3 months. Eucalypts wood chips was made with an 84 months Eucalypts forest. For comparison purposes the biomasses all analyses were carried out with completely dry biomass.

The component analyzes of biomass were carried out to determine the amounts of extractives, lignin and holocelluloses. The extractives content of biomass was determined according to the standard TAPPI T204 cm97(2007), only substituting ethanol/benzene with ethanol/toluene. Lignin content was determined according to Goldschimid (1971) and Gomide and Demuner (1986). Holocelluloses content was calculated by difference.

Biomasses were analyzed to determine the amounts of carbon, oxygen, hydrogen, nitrogen and sulfur were identified using a thermal conductivity detector, for which each element has a specific peak and interaction by Elemental Vario Micro Cube CHNS-O model, according to the DIN EN 15104 (2011).

\section{Bio-coal}

The pyrolysis of biomass was conducted in an electric laboratory oven using a container with approximately $0,003 \mathrm{~m}^{3}$. In all treatments, the container was filled completely with the biomass, and that was weighted before the pyrolysis. As shown in Figure 1, the heating control was conducted manually in increments of $50{ }^{\circ} \mathrm{C}$ every 30 minutes, which corresponds to an average heating rate $1,67^{\circ} \mathrm{C} \cdot \mathrm{min}^{-1}$. The initial temperature was 100 ${ }^{\circ} \mathrm{C}$ and the final temperatures were 400,550 and $700{ }^{\circ} \mathrm{C}$. After the process, bio-coal was weighted to calculate the gravimetric yield on the dry mass of biomass.

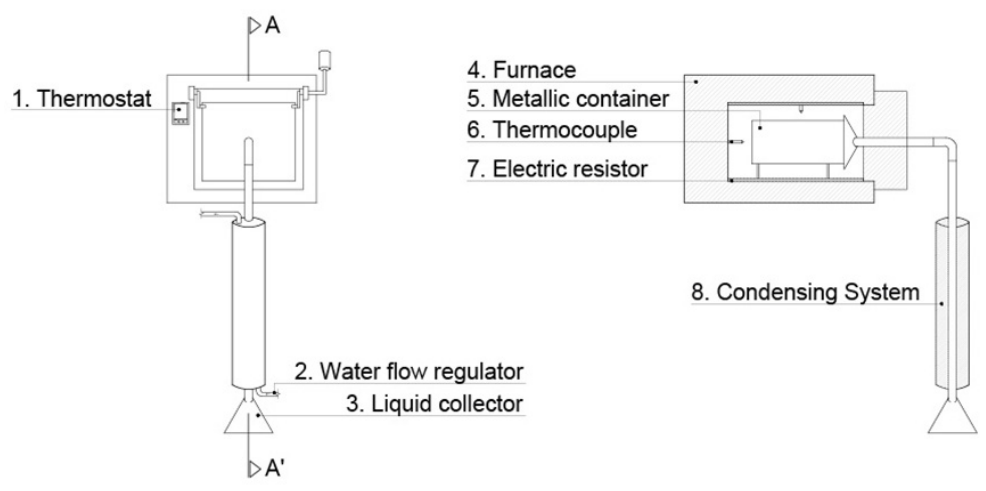

Figure 1: Schematic diagram of the pyrolysis reactor.

The high heating value of bio-coal was determined using an adiabatic calorimeter bomb IKA300 according to ASTM D240-02 (2007). Proximate analysis of bio-coal was done according to the standards ABNT NBR 8112 (1986) for volatile matter and ASTM D3174-04 (2010) for ash analysis. For these analyzes, charcoal crushed samples were used, which were passed through the 40-mesh sieve and retained in the 60-mesh sieve. Samples were oven dried at $103 \pm 2{ }^{\circ} \mathrm{C}$. Fixed carbon yield (\%) was calculated to investigate the efficiency of the pyrolysis using Equation 1.

$$
\text { Fixed carbon yield }(\%)=\frac{\text { biocoal yield } x(\text { biocoal fixed carbon })}{100-\% \text { biomass ash }}(1)
$$

\section{Experimental analysis}

The experiment was carried out in a randomized design double factorial $4 \times 3$ (four biomasses and three 
final temperatures of pyrolysis) with three replicates of each analyses, giving a total of 36 sampling units. Normality and homogeneity of the data were verified by Lilliefors and Cochran, respectively. Treatments were compared through Tukey test at 5\% probability.

\section{RESULTS AND DISCUSSION}

\section{Biomasses}

Table 1 shows the chemical composition of the raw biomasses. Eucalyptus contained the highest concentrations of holocelluloses and lignin, and lowest content of extractives and ash. Lowest holocelluloses and lignin were observed to the sugarcane bagasse and straw bean, respectively. Straw bean shows the highest values of the extractives and ash.

Table 1: Chemical composition of the biomasses.

\begin{tabular}{lcccc}
\hline Chemical Composition & Sugarcane Bagasse & Bamboo & Eucalypts & Straw Bean \\
\hline Holocelluloses (\%) & $53,1 \mathrm{c}$ & $56,8 \mathrm{~b}$ & $61,1 \mathrm{a}$ & $56,7 \mathrm{~b}$ \\
Lignins (\%) & $22,1 \mathrm{c}$ & $27,9 \mathrm{~b}$ & $31,7 \mathrm{a}$ & $15,4 \mathrm{~d}$ \\
Extractives (\%) & $19,7 \mathrm{~b}$ & $14,0 \mathrm{c}$ & $6,7 \mathrm{~d}$ & $21,1 \mathrm{a}$ \\
$\mathrm{C}(\%)$ & $42,48 \mathrm{~b}$ & $47,91 \mathrm{a}$ & $47,84 \mathrm{a}$ & $39,30 \mathrm{c}$ \\
$\mathrm{O}(\%)$ & $46,47 \mathrm{a}$ & $44,35 \mathrm{~b}$ & $44,77 \mathrm{~b}$ & $47,30 \mathrm{a}$ \\
$\mathrm{H}(\%)$ & $5,16 \mathrm{~b}$ & $5,57 \mathrm{~b}$ & $6,27 \mathrm{a}$ & $5,10 \mathrm{~b}$ \\
N (\%) & $0,76 \mathrm{~b}$ & $0,77 \mathrm{~b}$ & $0,61 \mathrm{~b}$ & $1,27 \mathrm{a}$ \\
$\mathrm{S}(\%)$ & $0,04 \mathrm{~b}$ & $0,05 \mathrm{~b}$ & $0,00 \mathrm{c}$ & $0,22 \mathrm{a}$ \\
$\mathrm{O} / \mathrm{C}$ & $0,82 \mathrm{a}$ & $0,69 \mathrm{~b}$ & $0,70 \mathrm{~b}$ & $0,90 \mathrm{a}$ \\
$\mathrm{H} / \mathrm{C}$ & $1,46 \mathrm{~b}$ & $1,39 \mathrm{c}$ & $1,57 \mathrm{a}$ & $1,56 \mathrm{a}$ \\
Ash $(\%)$ & $5,10 \mathrm{~b}$ & $1,35 \mathrm{c}$ & $0,50 \mathrm{c}$ & $6,82 \mathrm{a}$ \\
\hline
\end{tabular}

Means in the line followed by the same letter do not differ at $5 \%$ of probability by the Tukey Test.

The sum of hemicellulose and cellulose contents is called holocelluloses (Rowell et al. 2005). When biomass is used to produce energy or bio-coal, low levels of holocelluloses are preferred, since its components, hemicelluloses and cellulose, have low thermal resistance, due to these components do not contribute significantly to energy production or even for bio-coal yield (Yang et al. 2007, Shen et al. 2010, Haykiri-Acma et al. 2010).

The resistance of lignin in thermal degradation is higher than hemicelluloses and cellulose (White, 1987). The elevated level of aromaticity of its structure confers the lignin this feature (Xie et al. 2009). As far as the lignin content is concerned, eucalypts and bamboo biomass emerged as most prominent.

Straw bean showed the highest extractives content, $21,1 \%$, while eucalypts registered the least, $6,7 \%$. Based on their chemical nature the extractives can raise or lower the bio-coal yield. Straw bean revealed the highest concentration of nitrogen. Beans belong to Family Fabaceae in botanical classification and it can perform interactions with the nitrogen-fixing bacteria, thus raising the nitrogen concentration in the elemental biomass composition (Vitousek et al. 2013).

The bamboo and eucalypts biomasses showed the highest carbon concentration, mostly because of their higher lignin content. Eucalypts had the highest hydrogen content. The oxygen in straw bean and sugarcane bagasse were significantly high, possibly because of the lower lignin content and higher extractives content.

Higher percentages of carbon and hydrogen must be preferred, when the biomass is utilized to produce energy. The uses of biomass in a thermal treatment release energy from enthalpy of carbon, sulfur and hydro- 
gen (Pereira et al. 2013). On the other hand, the oxygen present in a biomass fuel reduces the energy released (Huang et al. 2009). The chemical composition assumes great significance when characterizing a fuel (Demirbas and Demirbas 2004).

It is observed that the straw bean presented the highest levels of nitrogen, because it is known that the beans are species of the Fabaceae family, and, therefore, capable of interacting with nitrogen-fixing bacteria. These bacteria can affect the biological fixation of nitrogen that, according to Vitousek et al. (2013), in the absence of human intervention, are the main source of $\mathrm{N}$ for the biosphere.

In addition to the energy capacity of renewable fuels, environmental aspects should be considered in terms of the amount of nitrogen and sulfur. If the biomass has high levels of nitrogen, during the pyrolysis, the formation and release of nitrous oxides and nitric acid to the atmosphere can occur and may cause negative environmental impacts (Yang et al. 2007, Pereira et al. 2013).

The percentage of inorganics presented variation from $0,5 \%$ (eucalypts) to $6,8 \%$ (straw bean). The highest inorganic contents were found for straw bean and sugarcane bagasse, respectively, because according to Scurlock et al. (2000), many herbaceous biomass materials (grasses and straws) have higher ash content.

It is not advantageous to have elevated inorganic compounds present in the biomass to produce bio-energy or bio-coal (Pereira et al. 2013). Besides being not degraded during the pyrolysis, these components can delay the combustion, causing corrosion that reduces the equipment lifetime and requires more cleaning.

\section{Bio-coal}

Figure 2 shows the average values of the proximate chemical composition (volatile matter, fixed carbon and ash) and high heating value (HHV) of bio-coal due to the final temperature of pyrolysis. The concentration of volatile matter dropped with the increase at the final temperature, except for the straw bean, with temperatures between 550 and $700{ }^{\circ} \mathrm{C}$, which were statistically equal.

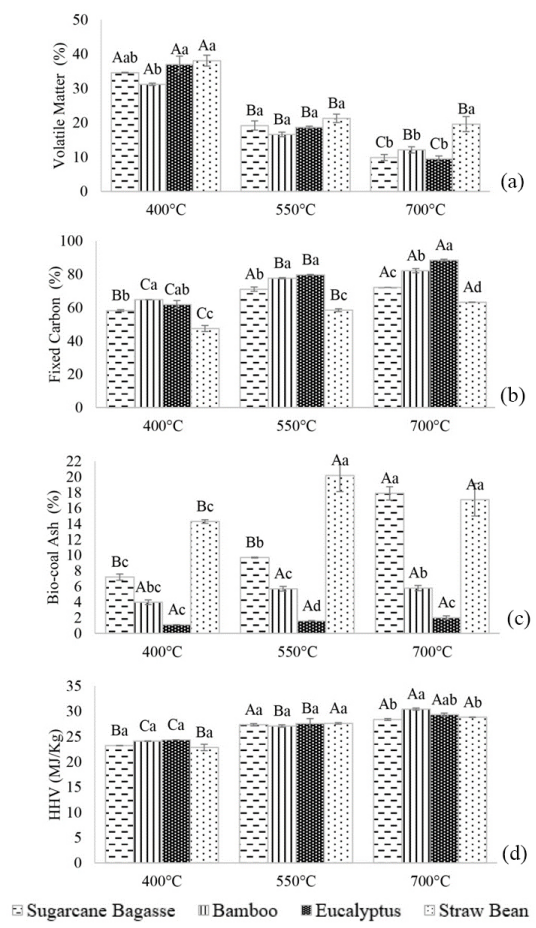

Figure 2: Mean values of Volatile Matter a) Fixed Carbon b) Ash c) Higher Heating Values (HHV) d) of bio-coal according to the final pyrolysis temperature.

Means followed by the same capital letter do not differ at 5\% probability by Tukey test between the final temperature of pyrolysis. Means followed by the same tiny letter do not differ at $5 \%$ probability by Tukey test between the biomasses. The error bar indicates the standard deviation of the mean.

There is an important link between the extractives, cellulose, hemicelluloses and the volatile matter (Perei- 
ra et al. 2013, Ramos-Carmona et al. 2017). As the final temperature of pyrolysis rises, more degradation of these compounds is noted, thus resulting in a decrease in the concentration of the volatile matter.

The highest ash was observed in bio-coal produced by raw biomasses, which also had higher ash content. The bio-coal from the eucalypts had the lowest ash content, and there were no significant differences between the final temperatures. Pereira et al. (2013) reported a positive correlation between the ash content of the biomass and the bio-coal ash. The inorganic compounds do not get degraded during the pyrolysis (Baysal et al. 2017). To minimize machinery wear and manpower for cleaning, the bio-coal should have the lowest possible ash content.

The bamboo and eucalypts bio-coal revealed the highest high heating value, 30,43 and 29,33 MJ.kg- ${ }^{1}$, respectively, not statistically different from each other. Notably, both these biomasses had high lignin content. The bio-coal produced at the higher final temperature showed a chemical composition with lower concentrations of volatile matter and higher amounts of fixed carbon and ash.

When the final temperature of pyrolysis was increased, it raises the high heating value of the bio-coal because of the higher fixed carbon content and dropped the volatile matter. The carbon in bio-coal during the pyrolysis process positively influenced the increase in the high heating value. According to Jenkins et al. (1998) the $1 \%$ increase in the carbon concentration of the bio-coal can raise its calorific value up to $0,39 \mathrm{MJ}_{\mathrm{kg}} \mathrm{kg}^{-1}$.

Figure 3 shows the average yields in the bio-coal and fixed carbon of the treatments are shown. Normally, the biomass properties determine the quality and yield of the bio-coal. In the current work, besides the chemical composition, the final pyrolysis temperature also greatly influenced the outcome.

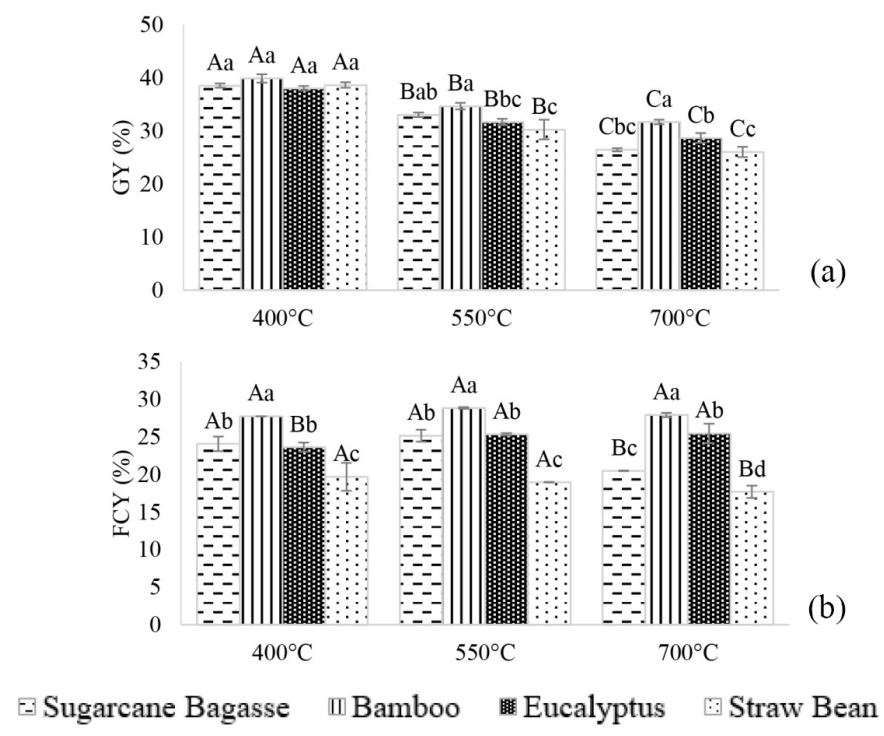

Figure 3: Mean values of gravimetric yield in bio-coal (GY) a) and fixed-carbon yield b) (FCY)

Means followed by the same capital letter do not differ at 5\% probability by Tukey test between the final temperature of pyrolysis. Means followed by the same tiny letter do not differ at $5 \%$ probability by Tukey test between the biomasses. The error bar indicates the standard deviation of the mean.

Overall, the biomass that showed a high lignin content, low extractives and ash showed the greatest yields of bio-coal. The fixed carbon content and bio-coal yield are inadequate, particularly when considered separately, to compare the potential of the biomass and efficiency of the bio-coal production method. The fixed 
carbon yield, including the bio-coal related quality, can be used as the process efficiency measure (Oyedun et al. 2012).

As show in Figure 3, when the final temperature of pyrolysis increases from 400 to $550{ }^{\circ} \mathrm{C}$, a reduction of gravimetric yield was observed. However, it not affects the fixed-carbon yield, once bio-coal fixed carbon increases. Eucalypts fixed-carbon yield rises in the temperature of $550{ }^{\circ} \mathrm{C}$, possibly due to its high lignin content. At the final pyrolysis temperature of $700^{\circ} \mathrm{C}$ a reduction of fixed-carbon yield was observed for sugar cane bagasse and straw bean.

Pyrolysis can be distinguished in two phases - the first one involves the pyrolysis of cellulose and hemicelluloses, in which the fixed-carbon yield continuously increases over time until it achieves a maximum value (Elyounssi et al.2010). This phase was observed in the fixed-carbon yield for all biomasses until $550{ }^{\circ} \mathrm{C}$ of final pyrolysis temperature, and at $700{ }^{\circ} \mathrm{C}$ for bamboo and eucalypts. The second phase begin with slow decomposition of lignins, including a drop in the fixed-carbon yield with rising residence time (Elyounssi et al. 2010). Due to the beginning of this second phase was observed a reduction in the fixed-carbon yield for sugarcane bagasse and straw bean.

\section{CONCLUSIONS}

These four biomasses analyzed in this study are widely available in Brazil with potential for bio-coal production. The best energy indicators for bio-coal production, such as fixed carbon yield, high heating value, was observed in the bamboo and eucalypts. The bagasse and straw bean biomasses possess high concentrations of ash and low lignins contents when compared with the other biomasses assessed and are less suitable to produce bio-coal.

In general, the analysis indicated that the largest lignins-containing biomass will support the yield of fixed carbon and strongly influences the properties of the bio-coal. The final temperature influences the yields and chemical composition of the bio-coal produced. This pyrolysis parameter depends mainly on the desired biocoal specifications, so it is up to each producer to use the temperature that best suits their final objective.

\section{ACKNOWLEDGEMENTS}

To Fundação de Amparo à Pesquisa do Estado de Minas Gerais (FAPEMIG), Conselho Nacional de Pesquisa e Desenvolvimento (CNPq), Empresa Brasileira de Pesquisa Agropecuária (Embrapa Florestas) and Thematic Group of Charcoal "G6".

\section{REFERENCES}

Associação Brasileira de Normas Técnicas. ABNT NBR. 1986. Carvão vegetal: análise imediata. ABNT NBR 8112- 1986. Rio de Janeiro, 8p.

ASTM D240-02. 2007. Standard Test Method for Heat of Combustion of Liquid Hydrocarbon Fuels by Bomb Calorimeter.American Society for Testing and Materials, Conshohocken, PA, USA.

ASTM D3174-04. 2010. Standard Test Method for Ash in the Analysis Sample of Coal and Coke from Coal. American Society for Testing and Materials, Conshohocken, PA, USA.

Bach, Q.V.; Skreiberg, O. 2016. Upgrading biomass fuels via wet torrefaction: A review and comparison with dry torrefaction. Renew Sustain Energy Rev 54: 665-677. 
Baysal, E.; Deveci, I.; Turkoglu, T.; Toker, H. 2017. Thermal analysis of oriental beech sawdust treated with some commercial wood preservatives. Maderas-Cienc Tecnol 19(3): 329-338.

Carrión-Prieto, P.; Martín-Ramos, P.; Hernández-Navarrol, S.; Sánchez-Sastre, L.F.; Marcos-Robles, J.L.; Martín-Gil, J. 2017. Valorization of Cistus ladanifer and Erica arborea shrubs for fuel: wood and bark thermal characterization. Maderas-Cienc Tecnol 19(4): 443-454.

Cerqueira, D.A.; Rodrigues, G.R.; Silva-Meireles, C. 2007. Optimization of sugarcane bagasse cellulose acetylation. Carbohydr Polym 69: 579-582.

Demirbas, A.; Demirbas, A.H. 2004. Estimating the Calorific Values of Lignocellulosic Fuels. Energy Explor Exploit 22: 135-144.

Deutsche Institut Für Normung. DIN. 2011. Determination of total content of carbon, hydrogen and nitrogen - Instrumental methods. DIN EN 15104- 2011. CEN: Berlin 15.

Dhyani, V.; Bhaskar, T. 2017. A comprehensive review on the pyrolysis of lignocellulosic biomass. Renew Energy 129: 695-716.

Elyounssi, K.; Blin, J.; Halim, M. 2010. High-yield charcoal production by two-step pyrolysis. J Anal Appl Pyrolysis 87: 138-143.

European Commission. 2012. Roadmap 2050, Policy 1-9.

Food and Agriculture Organization of the United Nations. 2017. FAOSTAT Statistics Division. 2017. Available at: <http://www.fao.org/faostat/en/\#data/FO>. (Accessed: 29 March 2019.

Goldschimid, O. 1971. Ultraviolet spectra. In: SARKANEN, K. V.; LUDWING, C. H. (Eds) Lignins. New York: Wiley Interscience 241-266.

Gomide, J.L.; Demuner, B.J. 1986. Determinação do teor de lignina em material lenhoso: método Klason modificado. O Papel 47: 36-38.

Grassmann, G.S.; Andrade, C.R.; Dias, A.F.; Silva, F.G.; Brito, J.O. 2016. Timber wastes torrefaction for energy use. Maderas-Cienc Tecnol 18(1): 105-112.

Haykiri-Acma, H.; Yaman, S.; Kucukbayrak, S. 2010.Comparison of the thermal reactivities of isolated lignin and holocellulose during pyrolysis. Fuel Process Technol 91: 759-764.

Heinemann, A.B.; Ramirez-Villegas, J.; Souza, T.L.P.O.; Didonet, A.D.; DiStefano, J.G.; Boote, K.J.; Jarvis, A. 2016. Drought impact on rainfed common bean production areas in Brazil. Agric For Meteorol 225: 57-74.

Huang, C.; Han, L.; Yang, Z.; Liu, X. 2009.Ultimate analysis and heating value prediction of straw by near infrared spectroscopy. Waste Management 29: 1793-1797.

Industria Brasileira de Arvores. IBA. 2017. Relatório 2017. 80p.

Jacalne, V. 1978. Above-Ground Biomass and the Growth of Bamboo Stands in the Philippines. Japan International Research Center for Agricultural Sciences, 1-7.

Jenkins, B.; Baxter, L.; Miles, T.; Miles, T. 1998.Combustion properties of biomass. Fuel Process Technol 54: 17-46.

Kwietniewska, E.; Tys, J. 2014. Process characteristics, inhibition factors and methane yields of anaerobic digestion process, with particular focus on microalgal biomass fermentation. Renew Sustain Energy Rev 34: 491-500.

Limayem, A.; Ricke, S.C. 2012. Lignocellulosic biomass for bioethanol production: Current perspectives, potential issues and future prospects. Prog Energy Combust Sci38: 449-467. 
Nath, A.J.; Das, G.; Das, A.K. 2008. Above ground biomass, production and carbon sequestration in farmer managed village bamboo grove in Assam, northeast India. J Am Bamboo Soc 21: 32-40.

Oyedun, A.O.; Lam, K.L.; Hui, C.W. 2012.Charcoal production via multistage pyrolysis. Chinese J Chem Eng 20: 455-460.

Pereira, B.L.C.; Carneiro, A. De C.O.; Carvalho, A.M.M.L.; Colodette, J.L.; Oliveira, A.C.; Fontes, M.P.F. 2013. Influence of Chemical Composition of Eucalyptus Wood on Gravimetric Yield and Charcoal Properties. BioResources 8: 4574-4592.

Pordesimo, L.O.; Edens, W.C.; Sokhansanj, S. 2004. Distribution of aboveground biomass in corn stover. Biomass and Bioenergy 26: 337-343.

Ramos-Carmona, S.; Pérez, J.F.; Pelaez-Samaniego, M.R.; Barrera, R.; Garcia-Perez, M. 2017. Effect of torrefaction temperature on properties of Patula pine. Maderas-Cienc Tecnol 19(1): 39-50.

Rowell, R.M.; Pettersen, R.; Han, J.S.; Rowell, J.S.; Tshabalala, M.A. 2005. Cell Wall Chemistry. In: Handbook of Wood Chemistry and Wood Composites. Rowell, R.M. (Ed.). Boca Raton: CRC Press 121-138.

Scurlock, J.M.O.; Dayton, D.C.; Hames, B. 2000. Bamboo: an overlooked biomass resource? Biomass and Bioenergy 19(4): 229-244.

Sermyagina, E.; Saari, J.; Kaikko, J.; Vakkilainen, E. 2015. Hydrothermal carbonization of coniferous biomass: Effect of process parameters on mass and energy yields. J Anal Appl Pyrolysis 113: 551-556.

Shen, D.K.; Gu, S.; Bridgwater, A. V. 2010. The thermal performance of the polysaccharides extracted from hardwood: Cellulose and hemicellulose. Carbohydrate Polymers 82: 39-45.

Sokhansanj, S.; Turhollow, A.; Cushman, J.; Cundiff, J. 2002. Engineering aspects of collecting corn stover for bioenergy. Biomass and Bioenergy 23: 347-355.

Technical Association of Pulp and Paper Industry. TAPPI. 2007. Solvent extractives of wood and pulp. TAPPIT204 cm-97 -. 2007. TAPPI test methods.

U.S. Congress. 2005. Public Law 109-58, 8 August 2005, Energy Policy Act of 2005. Available at: $<$ https://www.congress.gov/109/plaws/publ58/PLAW-109publ58.pdf $>$. (Accessed: 29 March 2018).

Valverde, S.R.; Soares, N.S.; Silva, M.L.; Jacovine, L.A.G.; Neiva, S.A. 2004. Comportamento do mercado da madeira de eucalipto no Brasil. Biomassa \& Energia 1: 393-403.

Varvel, G.E.; Vogel, K.P.; Mitchell, R.B.; Follett, R.F.; Kimble, J.M. 2008. Comparison of corn and switchgrass on marginal soils for bioenergy. Biomass and Bioenergy 32: 18-21.

Vitousek, P.M.; Menge, D.N.L.; Reed, S.C.; Cleveland, C.C. 2013. Biological nitrogen fixation: rates, patterns and ecological controls in terrestrial ecosystems. Philosophical Transactions of Royal Society B $368(1621)$.

Wang, S.; Dai, G.; Yang, H.; Luo Z. 2017. Lignocellulosic biomass pyrolysis mechanism: A state-ofthe-art review. Prog Energy Combust Sci 62: 33-86.

White, R.H. 1987. Effect of lignin content and extractives on the higher heating value of wood. Wood and Fiber Science 19(4): 446-452.

Xie, X.; Goodell, B.; Zhang, D.; Nagle, D.C.; Qian, Y.; Peterson, M.L.; Jellison, J. 2009. Characterization of carbons derived from cellulose and lignin and their oxidative behavior. Bioresource Technology 100: $1797-1802$.

Yang, H.; Yan, R.; Chen, H.; Lee, D.H.; Zheng, C. 2007. Characteristics of hemicellulose, cellulose and lignin pyrolysis. Fuel 86: 1781-1788.

Zhou, B.Z.; Mao-Yi, F.; Xie, J.Z.; Xiao-Sheng, Y.; Li, Z.C. 2005. Ecological functions of bamboo 
forest: Research and Application. Journal of Forestry Research 16: 143-147. 